\title{
A Ludic and Cultural Space for Beginner English Learners: Studying the Hippie Movement Songs and Lyrics
}

\author{
Espacio lúdico y cultural para estudiantes \\ principiantes de inglés: estudio de música y letras \\ del movimiento hippie
}

Rigoberto Castillo*, María Camila Garay Agudelo**; Paula Segura Soto

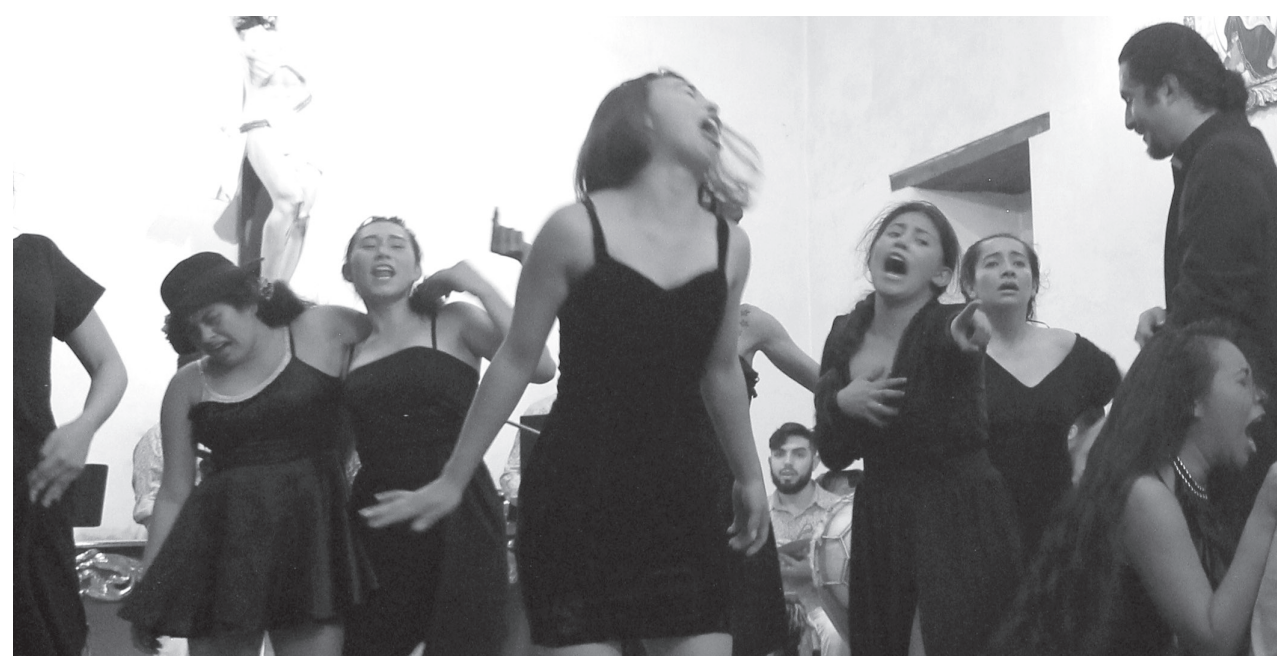

\begin{abstract}
This article reports a qualitative action research study on the contribution of using songs and lyrics to integrate cultural understanding and language development in an English as a foreign language (EFL) class at a middle school. We observed that our learners had difficulty to understand and express themselves in English. The social and cultural context of the late 1960's Hippie movement was the subject of the study through songs and lyrics. We offer our readers the most relevant literature and a synthesis of research reports on the subject to invite them to deepen in this topic.
\end{abstract}

Citar este artículo como: Castillo, R., Garay Agudelo, M. C. y Segura Soto, P. (2017). A Ludic and Cultural Space for Beginner English Learners: Studying the Hippie Movement Songs and Lyrics. Revista Papeles, 9(18), 11-20.

Fecha de recibido: octubre 1 de 2017.

Fecha de aceptación: diciembre 30 de 2017.

* Professor Rigoberto Castillo holds a Ph. D in Foreign Language Education from the University of Texas at Austin. He teaches at Universidad Distrital Francisco José de Caldas. Has published several books and articles in the field of Applied Linguistics. Correo: rcastillo@udistrital.edu.co

** María Camila Garay-Agudelo and Paula Segura-Soto are completing their studies in TEFL at Universidad Distrital Francisco José de Caldas. They have taught English at schools and other organizations. They have also presented at national events. Correos: mila.garay0895@gmail.com, pauvaleria28@gmail.com 
The findings of this qualitative study suggest that culture contextualized language and enhanced comprehension facilitates oral expression in EFL.

Key words: cultural awareness, EFL, genre, hippie movement, lyrics, songs.

\section{Resumen}

Este artículo reporta un estudio de investigación-acción cualitativo acerca de la contribución del uso de canciones y letras para integrar la comprensión cultural y el desarrollo del lenguaje en un salón de clase de inglés como lengua extranjera en educación media. Observamos que nuestros estudiantes tuvieron dificultades para comprender y expresarse en inglés. El contexto social y cultural de la última parte de los 60 del movimiento hippie fue el tema de estudio a través de las canciones y las letras. Ofrecemos a nuestros lectores la bibliografía y síntesis más relevantes del reporte de la investigación sobre el tema para invitarlos a profundizar en ella. Los hallazgos de este estudio cualitativo sugieren que la cultura contextualizó la lengua y mejoró la comprensión de las facilidades de la expresión oral del inglés como lengua extranjera.

Palabras clave: consciencia cultural, inglés como segunda lengua, género, movimiento hippie, canciones, letras.

\section{Introduction}

In addition to presenting the problem, the population, the literature, the research methodology, and the findings, this article provides a synthesis of research conducted on the topic of songs and lyrics that covers a decade. We hope our readership finds it useful.

Teaching a language encompasses the concepts of different context of customs, values and ideas. Halliday's defines context (Kramsch, 1998) as "a total environment in which text unfolds and of language as a part of reality, a shaper of reality" (p. 67). Some would argue that culture is implicit in learning another language and that belief may devalue the role of teaching culture. Hinkel (1999) reflects that cultural aspects of interaction and learning often appear mundane, but that these relationships influence the way in which the learning of a second culture can be carried out.

For Klippel (1994), the relationship between language and culture learning goes through three spheres: the empathy and understanding of a culture, the acquisition of knowledge about linguistics, and the development of communication. We plan to approach the empathy and the understanding stage. We concur with the idea that culture needs to be explicitly taught in the language classroom, then we chose songs representative of the hippie movement of 1960s. We assume that these pieces represent the multiplicity of a culture.

The use of songs in the language classroom has been recommended to enhance students' motivation but also to increase their knowledge. Using songs can be of benefit to enhance lexical, grammatical, phonological, sociolinguistic and cultural competencies (Engh, 2013). The analysis of lyrics allows students to identify unknown words, to focus on a specific aspect of grammar - if necessary - and to discover idioms and expressions, which are better understood by songs since these serve as contexts to clarify the meanings (Simpson, 2015). We consider that by choosing hippie movement songs, we could contribute to the understanding of others' thoughts and beliefs. 
They recognized simple and coordinated sentences, but had difficulty to convey meanings and messages in coordinated sentences. We noticed that their oral performance was below their familiarity with other aspects of English. This meant that although there was a display of knowledge of grammar and vocabulary, this was not evident in speaking since they were unable to organize and structure their ideas in coordinated sentences.

\section{The context and the problem}

The study took place at a secondary school in Bogota that serves over 1800 boys and girls with grades from pre-K to 11th. We chose a ninth grade. We took note of their knowledge in reading and writing tasks in which they displayed understanding of main ideas, basic notions of sentence construction and of paragraph organization. However, when we asked them to speak, there was a little participation, and those who participated seemed to struggle at uttering ideas; they could not put words in a string of sentences or express ideas in propositions.
They recognized simple and coordinated sentences, but had difficulty to convey meanings and messages in coordinated sentences. We noticed that their oral performance was below their familiarity with other aspects of English. This meant that although there was a display of knowledge of grammar and vocabulary, this was not evident in speaking since they were unable to organize and structure their ideas in coordinated sentences.

\section{Literature Review}

This study draws on the Constructivist and Functionalist perspective proposed by Taber (2011), which is discussed at the end of this section. Three constructs support our study: culture, music, and English language proficiency. Table 1, which appears in the appendix, summarizes representative research reports that relate to our constructs.

As for the first construct, we adhere to this definition of culture: "membership in a discourse community that shares a common social space and history, and common imaginings" (Kramsch, 1998 p. 10). The second construct is music defined as "a complex of activities, ideas, and objects that are patterned into culturally meaningful sounds" (Merriam, 1964 p. 27). The intersection of culture and music moved us to propose the pedagogical intervention with songs and lyrics within the structure of the social movement, Hippism. The third construct, English language proficiency, refers to the goal we pursue as teachers. It involves work to promote fluency: "the ability to communicate ideas effectively by producing written and/or spoken language with ease, [...] with a good but not necessarily perfect command of intonation, vocabulary, and grammar, [...] without causing comprehension difficulties or a breakdown of communication" (Richards \& Schmidt, 2002 p. 223).

Readers interested in doing further research in this topic can refer to Table 1 that appears in the Appendix, which presents the results of reliable research reports found in academic databases, libraries and repositories. We analyzed reports that dealt with promoting speaking through the use of music that were published in the last 10 years. The review of 


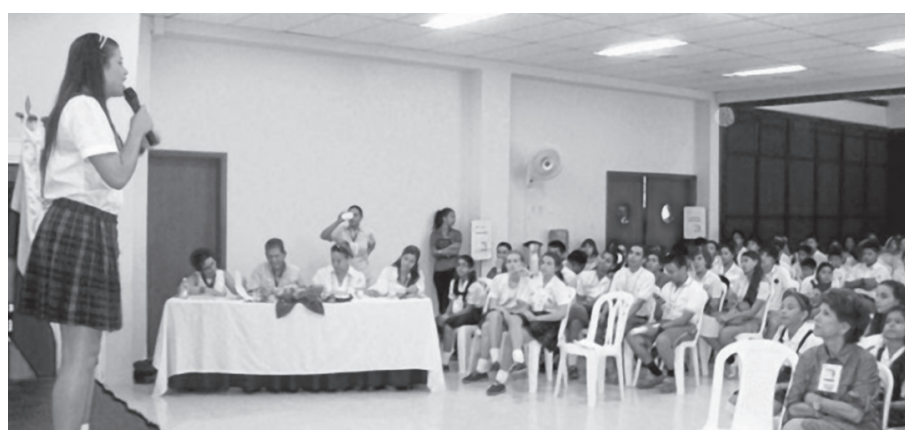

those reports served us to design the pedagogical intervention, the delimitation of this project and the use of action research.

The reports reviewed coincide in the importance of using music as an innovative resource different from the ones that are commonly used in the teaching practice. According to Şevik's (2011), teachers believe that songs should be an essential part of the curriculum and also that songs have a high pedagogical value to develop communicative skills and to offer more opportunities to show abilities in the FL. Following Şevik's ideas, Morales (2008) affirms that "the presence of music in diverse contexts and the variety of uses and situations in which it is involved are an important reason to believe that music plays a remarkable role in people's lives." The study of songs and lyrics implies working on communicative skills and can be connected with life events. Morales (2008) also says that the use of music "can release the practice of English from the pressure of academic duties, and help students face real use of the language in real contexts." Our middle school students relate to music; they listen to it, they talk about it. For them it is not only a way of expression but also a source of motivation.

Several authors like Morales (2008), Silva Ros (2006), Cuestas Cifuentes (2006) and Kuattiningsih (2007) agree that these criteria should be considered for selecting songs:

1. The vocabulary must be according to students' level.

2. Consider the problematic content lyrics include, such as references to violence, explicit language, etc.
3. Teaching songs should integrate the four language skills.

4. Songs should introduce the student to the creative use of the language.

For us the constructivist and functionalist perspective underlies this project. According to Taber (2011):

A learner comes to knowledge by recognizing the meaning of what is found in the environment. So the object or event in the environment -this could be anything- a chair, a chemical reaction, a utility bill on the doormat, a sentence read from a novel, the utterance of a teacher in a classroom- is assumed to have some inherent meaning, which the learner is able to identify, and so add to their store of knowledge about the world. (pp. 40-41).

This philosophical viewpoint about the nature of knowledge focuses on how learners make meaning based on the interaction between their ideas and experiences; when learners are given new information, they include it into an already existing knowledge without making any modification (assimilation) or learners can reframe their mental representations of the world to fit new information or experiences (accommodation).

Similarly, Halliday (in Bernstein, 2003), states that the functionalism:

Functionalism analyzes language in terms of the interrelated systems of choices that are available for expressing meaning. Basic to the approach is the notion that language structures cannot be idealized and studied without considering the circumstances of their use, including the extra linguistic social context. From this functional view, language acquisition needs to be seen as the mastery of linguistic functions. Learning one's mother tongue is learning the uses of language, and the meanings, or rather the meaning potential, associated with them. The structures, the words and the sounds are 
the realization of this meaning potential. Learning language is learning how to mean. (p. 345)

Our introduction of the study of songs and lyrics expresses our wish of discussing the extra linguistic social context of Hippism for ninth graders to understand linguistic processes and structures, belonging to the 1960's period in which a language and a music expression developed.

\section{Research Method}

The participants were 36 students of a class of ninth grade with boys and girls between 13 and 15 years old. Participants had a basic level, so it seemed appropriate to stress vocabulary learning on the topic of hippie movement.

For the planning stage of the action research, and to narrow down the topic, the research team chose these characteristics of hippism: a) promotion of a gentle ideology that focused on peace, love, and personal freedom; b) aversion to commercialism, superficial values and materialistic people; c) love is free; life is not what others think you should be. Table 2 presents the characteristic of hippism debated and the corresponding pedagogical task.

In the execution stage, lessons present the background, the artist and the lyrics. Students listened to the songs reading the lyrics followed by a round table about the interpretations of meanings and messages. Sessions concluded with the students writing their own ideas about the topic.

\section{Pedagogical Intervention}

Developmental processes take place through participation in cultural, linguistic, and historically formed settings such as family life, school life and peer group interaction: We chose the genre lyrics to promote language proficiency development. Hyland (2007) defines genre as "abstract, socially recognized ways of using language."

On the other hand, Coats (2016) affirms that both linguistic genres and music genres carry implicit information shared by a discourse community. In the case of hippism, rock and
In the evaluation stage, we assessed speaking by analyzing recordings of the sessions and recordings brought by ninth graders. For the group assessment, they presented their favorite song or artist with emphasis on the cultural aspects of the lyrics.

The preliminary data to identify the problem, the literature review, and key research reports allowed us to formulate these research questions:

- How may the analysis of hippie songs and lyrics enhance cultural awareness?

- How may the use of songs and lyrics contribute to the development of English language proficiency?

This inquiry implied a pedagogical innovation beyond language skills in which a historical background explains a cultural phenomenon. The following section expands on that. roll served as a vehicle to highlight historical facts, and transmit a message of empowerment and made society reflect about something in particular. Having this in mind, Coats (2016) proposes five aspects of analysis, which "incorporate micro-level linguistic features that students need for interpreting song lyrics and macro-level comprehension that draws on students' background knowledge and provides a context for understanding perspectives of the target culture to which the song lyrics are inextricably connected." 
The components, considered for selecting the songs, are:

- Big picture: Background and points of view of the song

- Imagery: Cultural references in the song

- Language use: The type of language chosen by composers

- Grammar: Grammatical features presented in the song
- Personal response: Students personal opinion

Accordingly, there were two lessons for each feature with one or two songs. Woodstock, a documentary, introduced the topic. We narrowed the inquiry to key features that appear in Table 2. These characteristics reflect what Bhaddock (2014) said about Hippies; they held that life was about being happy, not about what others thought you should be.

Table 2. Characteristics of Hippism Represented in Songs. (Own Production)

\begin{tabular}{|l|l|l|}
\hline \multicolumn{1}{|c|}{ Feature of Hippism } & \multicolumn{1}{c|}{ Name of the song } & \multicolumn{1}{c|}{ Artist } \\
\hline General introduction to Hippie movement & Woodstock & Joni Mitchell \\
\hline Promote a gentle ideology that focused on & Imagine & John Lennon \\
\cline { 2 - 3 } peace, love, and personal freedom. & The Night They Drove Old Dixie Down & Joan Baez \\
\hline $\begin{array}{l}\text { Aversion to commercialism: Superficial } \\
\text { values and materialistic people }\end{array}$ & Mercedes Benz & Janis Joplin \\
\cline { 2 - 3 } $\begin{array}{l}\text { Life is not what other think you should be. } \\
\text { Love is free. }\end{array}$ & Like A Rolling Stone & Bob Dylan \\
\cline { 2 - 3 } & Lola & The Beatles \\
\hline Closing to the topic & Chosen by students & The Kinks \\
\hline
\end{tabular}

\section{Results and Discussion}

Students showed improvement in communication skills and cultural awareness. As they moved on to a different feature, their language and their thoughts reflected understanding. Their comments were complemented and supported by the knowledge they had gained. For example, ninth graders shared comments they had written stating what they learned about the hippies:

- What I learned was the life of the hippies they have love for nature and their ... is love and peace (student 5)

- I learned that hippies want the peace of the world and that they are very pacifists, they express themselves through their songs, they represent a lot of peace (student 3 )

- The hippies were from the world. The hippies want worldwide peace and the love. The culture is based on the sing the good of people. They are very debots* (devoted) to their culture (student 6).
We attribute their learning to the contact and study with contextualized situations; we felt we built a bridge between language and culture. Furthermore, we noticed that compensation learning strategies, like switching to mother tongue, helped overcome limitations in speaking, and so did the elaboration of posters for making group and whole class oral presentations as the one below that reads John Lennon [It] was a musician multi-instrumentalist one of the founders of the Beatles.

Figure 1. Picture of student No. 5 (poster).

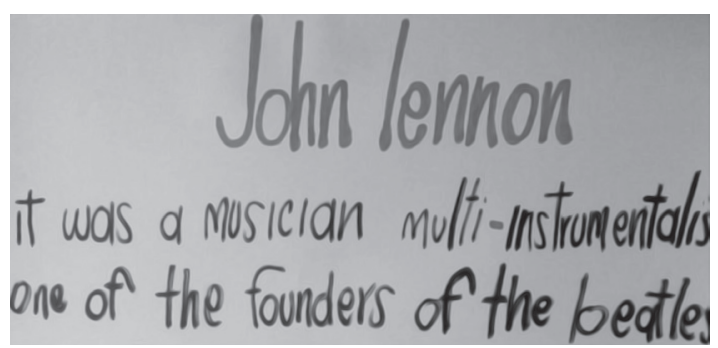


Good results are attributable to the combination of individual and group work. Individual work provided each student the opportunity to reflect on their beliefs while group work gave them a chance to contrast personal values and experiences with those of others. We also found that tasks of free expression, focusing on the message, not on grammar helped participation and motivation.
We confirmed the assertion that the relationship between language and culture learning goes through three spheres: the empathy and understanding of a culture, the acquisition of knowledge about linguistics, and the development of the communicative skill (Klippel, 1994). We approached empathy with songs and lyrics that represented the multiplicity of a culture, for they offer a view towards the understanding of others' thoughts and beliefs.

\section{References}

Bhaddock. (2014). The Hippie Counter Culture Movement (1960's). Retrieved from Mortal Journey: http://www.mortal journey.com/2011/03/1960-trends/hippie -counter-culture-movement

Ballesteros, C., Bocigas, M. O., \& Montoya, A. (2015, Agosto). Singing Consumption: Discourse Analysis and Consumption Driven Values that Underlies Lyrics. Boletín de Estudios Económicos, 70(215), 347-368. Retrieved from https://issuu.com/deustobusinessalumni/ docs/215-agosto_2015

Batluk, L. (2015). Does Listening to English Songs Motivate Students to Expand Their Extramural English? A Case Study of Swedish Upper-Secondary School Students' Perceptions of Possible Impact of Listening to Vocal Music on Their Extramural English. . Retrieved from http:// lnu.diva-portal.org/smash/get/diva2:817139/ FULLTEXT01.pdf

Bentayeb, N. (2006). Improving the Students' Speaking Skill Through the use of English Songs. A Case Study of First Year Students at the Department of English. Retrieved from http:// thesis.univ-biskra.dz/id/eprint/1695

Bernstein, B. (2003). Class, Codes, and Control (Vol. II). London: Routledge.

Bhaddock. (2014). The Hippie Counter Culture Movement (1960's). Retrieved from Mortal Journey: http://www.mortaljourney.com/2011 /03/1960-trends/hippie-counter-culturemovement

Buket, E. (2010). The Effects of Music on English Language Learners' Spaking Fluency and on their Motivation/Interest Level. Retrieved from http://www.thesis.bilkent.edu.tr/0003898.pdf

Castro Huertas, I. A., \& Navarro Parra, L. J. (2014). The Role of Songs in First-Graders' Oral Communication Development in English. PROFILE Issues in Teachers' Professional Development, 16(1), 11-28. Retrieved from https://dialnet.unirioja.es/servlet/articulo? codigo $=4858479$

Coats, G. (2016). Analyzing song lyrics as an authentic language learning opportunity. Report of the Central States Conference on the Teaching of Foreign Languages. 1, pp. 1-22. Lincoln: University of Nebraska. Retrieved from https://csctfl.wildapricot.org/resources/ Documents/2016Report/2016\%20Report.pdf

Cuestas Cifuentes, M. (2006). Songs in the English Class. A Strategy to Encourage Tenth Graders' Oral Production. PROFILE Issues in Teachers' Professional Development, 7(1), 47-57. Retrieved from https://dialnet.unirioja. es/servlet/articulo? codigo $=4858596$

De Castro Martínez, N. (2014). El uso de la Música para la enseñanza del Inglés. El Lipdub. Retrieved from https://uvadoc.uva.es/bitstream/10324/8415/1/TFG-O\%20410.pdf 
Diakou, M. (2013). Using Songs to Enhance Language Learning and Skills in the Cypriot Primary EFL Classroom. Retrieved from http:// oro.open.ac.uk/42726/1/DoctorateinEducationMariaDiakou.pdf

Duarte Romero, M., Tinjacá Bernal, L. M., \& Carrero Olivares, L. M. (2012). Using Songs to Encourage Sixth Graders to Develop English Speaking Skills. PROFILE Issues in Teachers' Professional Development, 14(1), 11-28. Retrieved from https://dialnet.unirioja.es/ servlet/articulo?codigo $=4858700$

Engh, D. (2013). Effective Use of Music in Language-Learning: A Needs Analysis. Retrieved from Humanising Language Teaching: http:// www.hltmag.co.uk/oct13/mart03.htm

Hinckle, W. (1967). The Social History of the Hippies. Ramparts Magazine, 5-26.

Hyland, K. (2007). Genre pedagogy: Language, literacy and. Journal of Second Language Writing, 148-164.

Jurío, I. (2014). El uso de las canciones en el aula de inglés de primaria. Retrieved from http://biblioteca.unirioja.es/tfe_e/TFE000742. pdf

Klippel, F. (1994). Cultural Aspects in Foreign Language Teaching. Journal for the Study of British Cultures, 1(94), 49-61. Retrieved from https://core.ac.uk/download/pdf/12169523. pdf

Kramsch, C. (1998). Language and Culture. Oxford: Oxford University Press.

Kuattiningsih, N. (2007). The Use of Songs to Teach English Vocabulary to Year 2 Students of SD Negeri Sekip I No. 161 Surakarta. Retrieved from https://eprints.uns. ac.id/7220/1/78051607200904351.pdf

Lee, L., \& Lin, S.-C. (2015). The Impact of Music Activities on Foreign Language, English Learning for Young Children. Journal of the European Teacher Education Network, 10, 13-23. Retrieved from http://jeten-online.org/ index.php/jeten/article/download/63/53
Merriam, A. P. (1964). The Anthropology of Music. Illinois: University Press.

Morales, C. (2008). Using Rock Music as a Teaching-Learning Tool. PROFILE Issues in Teachers' Professional Development(9), 163-180. Retrieved from http://www.redalyc. org:9081/articulo.oa?id=169213804010

Palacios, N., \& Chapetón, C. M. (2014). Students' Responses to the Use of Songs in the EFL Classroom at a Public School in Bogotá: A Critical Approach. GIST Education and Learning Research Journal(9), 9-30. Retrieved from http://files.eric.ed.gov/fulltext/EJ1062661.pdf Pedraza Pineda, S. P. (2015). El karaoke como herramienta mediadora para fortalecer la oralidad en la clase de inglés como lengua extranjera. Retrieved from http://repository.unilibre.edu.co/bitstream/ handle/10901/8426/EL\%20KARAOKE\%20 COMO\%20HERRAMIENTA\%20MEDIADORA\%20PARA\%20FORTALECER\%20LA\%20 ORALIDAD\%20EN\%20LA\%20CLASE\%20 DE\%20INGLES\%20COMO\%20LENGUA\%20 EXTRANJERA.pdf?sequence $=1$

Richards, J. C., \& Schmidt, R. W. (2002). Longman Dictionary of Language Teaching and Applied Linguistics. London: Routledge.

Şevik, M. (2011). Teacher views about using songs in teaching English. Educational Research and Review, 6(21), 1027-1035. Retrieved from http://www.academicjournals. org/article/article1379844804_Sevik.pdf

Silva Ros, M. T. (2006). La enseñanza del Inglés como lengua extranjera en la titulación de Filología Inglesa: El uso de canciones de música popular no sexistas como recurso didáctico. (U. d. Málaga, Editor) Retrieved from Doctoral Thesis: http://www.biblioteca.uma.es/bbldoc/ tesisuma/16853805.pdf

Simpson, A. J. (2015). How to use songs in the English language classroom. Retrieved 2016, from British Council: https://www. britishcouncil.org/voices-magazine/ how-use-songs-english-language-classroom 
Sotelo, E. R. (2011). Impementación de una metodología de aprendizaje del idioma inglés basado en la música como recurso didáctico. Retrieved November 29, 2017, from http:// repository.unilibre.edu.co.

Taber, K. (2011). Constructivism as educational theory: contingency in learning, and optimally guided instruction. In Educational Theory (pp. 39-61). New York: Nova Science Publishers Inc. Retrieved from http:// people.ds.cam.ac.uk/kst24/KeithSTaber/ Constructivism_files/Taber,\%20K.\%20S.\%20 $\% 282011 \% 29 . \% 20$ Constructivism\%20as\%20 educational\%20theory.pdf
Tayari, F., \& Mahdavi, A. (2015). The Effect of English Verbal Songs on Connected Speech Aspects of Adult English Learners' Speech Production. Advances in Language and Literary Studies, 6(1), 212-226. Retrieved from http://www.journals.aiac.org.au/index.php/ alls/article/view/1309/1299

Ward, B. (n.d.). What's That Sound? Teaching the 1960s through Popular Music. Retrieved from The Gilder Lehrman institute of American History: https://www.gilderlehrman.org/history-by-era/sixties/resources/ wh at $\%$ E $2 \% 80 \% 99$ s - s ound - teaching1960s-through-popular-music

\section{Appendix}

Table 1. Summary of Research Reports Relevant to this Study. (Own production).

\begin{tabular}{|c|c|c|c|c|}
\hline & Author, year & Problem or issue & $\begin{array}{l}\text { Population and } \\
\text { length of study }\end{array}$ & $\begin{array}{l}\text { Research } \\
\text { method }\end{array}$ \\
\hline 1 & (Morales, 2008) & $\begin{array}{l}\text { Using Rock Music as a Teaching- } \\
\text { Learning Tool }\end{array}$ & $\begin{array}{l}\text { Two students, Daniel (21) } \\
\text { and Alfredo (27). }\end{array}$ & $\begin{array}{l}\text { Qualitative } \\
\text { research }\end{array}$ \\
\hline 2 & (Engh, 2013) & $\begin{array}{l}\text { Effective Use of Music in Language- } \\
\text { Learning: A Needs Analysis }\end{array}$ & $\begin{array}{l}\text { Secondary and post-sec- } \\
\text { ondary teachers who teach } \\
\text { teen and adult learners }\end{array}$ & Not stated \\
\hline 3 & (Diakou, 2013) & $\begin{array}{l}\text { Using Songs to Enhance Language } \\
\text { Learning in a Cypriot Primary EFL } \\
\text { Classroom }\end{array}$ & Primary EFL classroom & $\begin{array}{l}\text { Ethnographic case } \\
\text { study framework }\end{array}$ \\
\hline 4 & $\begin{array}{l}\text { (Kuattiningsih, } \\
\text { 2007) }\end{array}$ & $\begin{array}{l}\text { The use of songs to teach English } \\
\text { vocabulary to year } 2 \text { students of SD } \\
\text { Negeri Sekip I No.161 Surakarta }\end{array}$ & $\begin{array}{l}\text { Year two students of SD } \\
\text { Negeri Sekip I No.161 } \\
\text { Surakarta }\end{array}$ & Not stated \\
\hline 5 & (Lee \& Lin, 2015) & $\begin{array}{l}\text { The Impact of Music Activities on } \\
\text { Foreign Language, English Learning } \\
\text { for Young Children }\end{array}$ & $\begin{array}{l}\text { A group of children at age } \\
\text { four }\end{array}$ & $\begin{array}{l}\text { Quantitative } \\
\text { analysis and } \\
\text { qualitative study }\end{array}$ \\
\hline 6 & $\begin{array}{l}\text { (Tayari \& Mahdavi, } \\
\text { 2015) }\end{array}$ & $\begin{array}{l}\text { The Effect of English Verbal Songs on } \\
\text { Connected Speech Aspects of Adult } \\
\text { English Learners' Speech Production }\end{array}$ & $\begin{array}{l}40 \text { participants of an inter- } \\
\text { mediate level in a language } \\
\text { institute in Tehran }\end{array}$ & Not stated \\
\hline 7 & $\begin{array}{l}\text { (Duarte Romero, } \\
\text { Tinjacá Bernal, \& } \\
\text { Carrero Olivares, } \\
\text { 2012) }\end{array}$ & $\begin{array}{l}\text { Using Songs to Encourage Sixth Grad- } \\
\text { ers to Develop English Speaking Skills. }\end{array}$ & $\begin{array}{l}84 \text { sixth graders who } \\
\text { belonged to two different } \\
\text { classrooms: } 601 \text { and } 602\end{array}$ & Action research \\
\hline 8 & (Şevik, 2011) & $\begin{array}{l}\text { Teacher views about using songs in } \\
\text { teaching English to young learners }\end{array}$ & $\begin{array}{l}52 \text { Turkish EFL primary } \\
\text { teachers }\end{array}$ & Descriptive study \\
\hline 9 & (Batluk, 2015) & $\begin{array}{l}\text { Students' Perceptions of Possible } \\
\text { Impact of Listening to Vocal Music on } \\
\text { Their Extramural English }\end{array}$ & $\begin{array}{l}\text { A group of Swedish upper- } \\
\text { secondary students }\end{array}$ & $\begin{array}{l}\text { Case study - Qual- } \\
\text { itative research }\end{array}$ \\
\hline 10 & $\begin{array}{l}\text { (De Castro } \\
\text { Martínez, 2014) }\end{array}$ & $\begin{array}{l}\text { El uso de la Música para la enseñanza } \\
\text { del inglés. El Lipdub. }\end{array}$ & $\begin{array}{l}\text { A classroom in primary } \\
\text { education level }\end{array}$ & Not stated \\
\hline
\end{tabular}




\begin{tabular}{|c|c|c|c|c|}
\hline & Author, year & Problem or issue & $\begin{array}{l}\text { Population and } \\
\text { length of study }\end{array}$ & $\begin{array}{c}\text { Research } \\
\text { method }\end{array}$ \\
\hline 11 & (Jurío, 2014) & $\begin{array}{l}\text { El uso de las canciones en el aula de } \\
\text { inglés de Primaria }\end{array}$ & & Not stated \\
\hline 12 & $\begin{array}{l}\text { (Pedraza Pineda, } \\
\text { 2015) }\end{array}$ & $\begin{array}{l}\text { El karaoke como herramienta media- } \\
\text { dora para fortalecer la oralidad en la } \\
\text { clase de inglés LE }\end{array}$ & A $5^{\text {th }}$ grade in Colombia & Action research \\
\hline 13 & (Sotelo, 2011) & $\begin{array}{l}\text { Implementación de una metodología } \\
\text { de aprendizaje del idioma inglés } \\
\text { basado en la música como recurso } \\
\text { didáctico }\end{array}$ & $\begin{array}{l}20 \text { students between } 17 \text { and } \\
60 \text { years old }\end{array}$ & $\begin{array}{l}\text { Quantitative } \\
\text { research }\end{array}$ \\
\hline 14 & $\begin{array}{l}\text { (Palacios \& } \\
\text { Chapetón, 2014) }\end{array}$ & $\begin{array}{l}\text { Students' Responses to the Use of } \\
\text { Songs in the EFL Classroom in Bogotá: } \\
\text { A Critical Approach }\end{array}$ & A group of 11th graders & $\begin{array}{l}\text { Action research } \\
\text { study }\end{array}$ \\
\hline 15 & $\begin{array}{l}\text { (Castro Huertas } \\
\text { \& Navarro Parra, } \\
\text { 2014) }\end{array}$ & $\begin{array}{l}\text { The Role of Songs in First-Graders' } \\
\text { Oral Communication Development in } \\
\text { English }\end{array}$ & \begin{tabular}{|l|} 
Children between six and \\
seven years old who were \\
in first grade at a public \\
school in Usaquén (Bogotá, \\
Colombia)
\end{tabular} & Action Research \\
\hline 16 & $\begin{array}{l}\text { (Cuestas Cifuentes, } \\
\text { 2006) }\end{array}$ & $\begin{array}{l}\text { Songs in the English Class: A Strategy } \\
\text { to Encourage Tenth Graders' Oral } \\
\text { Production }\end{array}$ & $\begin{array}{l}45 \text { tenth graders divided } \\
\text { into small groups of } 5 \text { or } 6 \\
\text { students }\end{array}$ & Action research \\
\hline 17 & (Buket, 2010) & $\begin{array}{l}\text { The effects of music on English lan- } \\
\text { guage learners' speaking fluency and, } \\
\text { on their motivation, /interest level }\end{array}$ & $\begin{array}{l}46 \text { pre-intermediate level } \\
\text { students at a Technical } \\
\text { University. }\end{array}$ & Not stated \\
\hline 18 & (Bentayeb, 2006) & $\begin{array}{l}\text { Improving the Students' Speaking Skill } \\
\text { Through the use of English Songs. } \\
\text { Study of First Year Students at the } \\
\text { Department of English. }\end{array}$ & $\begin{array}{l}\text { Students from the first } \\
\text { year, divide them into an } \\
\text { experimental group and a } \\
\text { control group. }\end{array}$ & Experimental \\
\hline 19 & (Silva Ros, 2006) & $\begin{array}{l}\text { La enseñanza del inglés como lengua } \\
\text { extranjera en la titulación de Filología } \\
\text { Inglesa: El uso de canciones de música } \\
\text { popular no sexistas como recurso } \\
\text { didáctico. }\end{array}$ & $\begin{array}{l}75 \text { students of first and } \\
\text { second English Language } \\
\text { course of the degree in } \\
\text { English Philology. }\end{array}$ & Not stated \\
\hline
\end{tabular}

